\title{
Morphological and Biochemical Properties Useful for Identification of Erwinia chrysanthemi
}

\author{
B.A. Vasundhara* and N. Thammaiah \\ Department of Horticultural Plant Pathology, K.R.C. College of Horticulture, \\ Arabhavi- 591 218, Karnataka, India \\ *Corresponding author
}

A B S T R A C T

\section{Keywords}

Pathogenicity test, Hypersensitive reaction, Erwinia chrysanthemi.

Article Info

Accepted: 04 September 2017 Available Online: 10 October 2017
Rhizome rot or tip over disease of banana has been occurring in serious form and affecting the yield wherever bananas are being cultivated. The morphological characteristics of the eighteen isolates of the bacterium revealed that cells were rod shaped, occurred singly, Gram negative and peritrichously flagellated. The pathogen was identified on the basis of cultural, morphological and biochemical characteristics and its pathogenicity in banana was proved using Koch's postulates. The identity of the pathogen was also confirmed by the manifestation of characteristic water soaked, necrotic lesion on tobacco leaves.

\section{Introduction}

Rhizome rot or tip over disease of banana incited by Erwinia chrysanthemi is a serious disease causing rotting of newly planted rhizomes with failure to sprout, stunting and yellowing of young plants. It is a major constraint for commercial cultivation of banana. Several workers have reported in the fast from India. Edward et al., (1973) noticed 'Tip over' or 'bacterial rot' in a small piece of land with alluvial soil located close to Yamuna River for the first time on variety Basarai banana in 1968 from India, and isolated a strain of Erwinia carotovora from rotting parts of rhizome. Chattopadhyay and Mukherjee (1986) reported the pseudostem of banana caused by Erwinia chrysanthemi pv. paradisiaca on Gaint Governor in West
Bengal. Lakshmanan and Mohan (1986) observed tip over disease or head rot caused by Erwinia carotovora in Tamil Nadu in North Arcot and Trichy districts. Dickey and Victoria (1980) reported that, the strain from $M$. paradisiaca in Colambia was very similar to E. chrysanthemi on the basis of biochemical and physiological properties. Snehalatharani and Khan, (2010) reported the bacterium showing positive for pectate degradation on CVP medium, growth at $36^{\circ} \mathrm{C}$ and $39^{\circ} \mathrm{C}$, catalose production and negative for indole production. Further they gave positive result for the production of acid from various agars such as lactose, trehalose, maltose and cellobiose and soft rot of inoculated potato slices. 
Biochemical and pathogenicity test indicated that the isolates are Erwinia chrysanthemi. This work deals with pathogenicity test, hypersensitive, morphological and biochemical characterisation of Erwinia chrysanthemi causing tip-over disease of banana.

\section{Materials and Methods}

\section{Morphological characteristics}

The morphological characteristics of the eighteen isolates with respect to shape, Gram reaction and flagella staining, were studied as described by Society of American Bacteriology (Anon., 1957), Stover (1959), Bradbury (1970) and Dickey (1981).

\section{Pathogenicity test}

The pathogenicity test was carried out on 20 banana plants. The bacterial isolates were multiplied on nutrient agar plates. The bacterial cultures were harvested and suspended in sterile water and adjusted turbidometrically to give a cell concentration of $5 \times 10^{7} \mathrm{cfu} / \mathrm{ml}$ and also viable cell counts were made by dilution plate method.

\section{Proving the Koch's postulates}

The healthy susceptible tissue cultured Grand Naine plantlets were used in this study. The plantlets were washed to remove the traces of soil adhering to the root surface and roots were injured by using sterile blade for entry of the pathogen. The rhizomes were dipped in the bacterial suspension for 45 minutes, control plants were dipped in sterile distilled water and planted in the earthen pots containing sterilized soil and pots were maintained in the polyhouse. Observations were recorded for the appearance and development of symptoms. After symptoms development, reisolation was done from the artificially infected plants. The isolate obtained was compared with the original culture for confirmation.

\section{Hypersensitive reaction on tobacco (hr)}

The bacterial isolates obtained from the infected rhizome tissues and multiplied in the nutrient broth. The bacterial cells were suspended in sterile distilled water and the concentration of the cell suspension was adjusted to $2 \times 10^{8} \mathrm{cfu} / \mathrm{ml}$. The bacterial cell suspension was adjusted in to the intercellular spaces of intact tobacco leaves (Nicotiana tobaccum) with a hypodermic needle. The infected plants were kept in the glass house at $28{ }^{\circ} \mathrm{C}$ to $30{ }^{\circ} \mathrm{C}$. The plants were observed for the development of necrotic lesions. Leaves injected with sterilized distilled water served as control.

\section{Biochemical characteristics}

The bacterial isolates were tested for the physiological and biochemical characteristics with regard to potato soft rot, gelatine liquefaction, sensitivity to erythromycin, indole production, phosphatase test, growth at 36 to $37^{\circ} \mathrm{C}$. The tests were conducted as per the methods described by Dickey and Victoria (1980) and Dickey (1981).

\section{Results and Discussion}

\section{Morphological characteristics}

The morphological characteristics of the eighteen isolates of the bacterium revealed that cells were rod shaped, occurred singly, Gram negative and peritrichously flagellated (Plate 1). Similar results were reported by Stover (1959) who reported that the bacterium is motile gram-negative, rod shape. Schaad and Brenner (1977) reported that cells of the bacterium were Gram-negative, peritrichous, rod shape. Dickey and Victoria (1980) reported that bacterium isolated from $M$. paradisiaca was a gram negative, non-spore 
forming rod shape. Snehalatharani and Khan (2010) reported that the bacterium was rod shaped, gram negative, peritrichously flagellated, non-spore forming and non-acid fast.

\section{Pathogenicity test}

The bacterial cultures were artificially inoculated to 20 banana seedlings by rhizome dip technique. The leaves in the inoculated plants started turning yellow and which later on became brown and dried after 25-30 days after inoculation. The rhizomes were found discoloured dark brown to black, rotted and emitted foul smell, reisolation was done for the artificially infected plants. The isolates were compared with original isolates thus confirming the identity of the pathogen (Plate 2). Similar findings were made by Stover (1959) who reported that the disease symptoms in above ground parts appeared in 8 -10 weeks after inoculated rhizomes were planted in pots. Lakshmanan and Mohan (1992) reported that the pathogenicity was proved by soaking the suckers in a bacterial suspension of virulent strains $\left(7 \times 10^{7} \mathrm{cfu} / \mathrm{ml}\right)$ for 15 minutes. Pathogenicity test of bacteria was successfully done by artificial inoculation method at Arabhavi centre (Anon., 2009).

\section{Plate.1 Growth of Erwinia chrysanthemi}
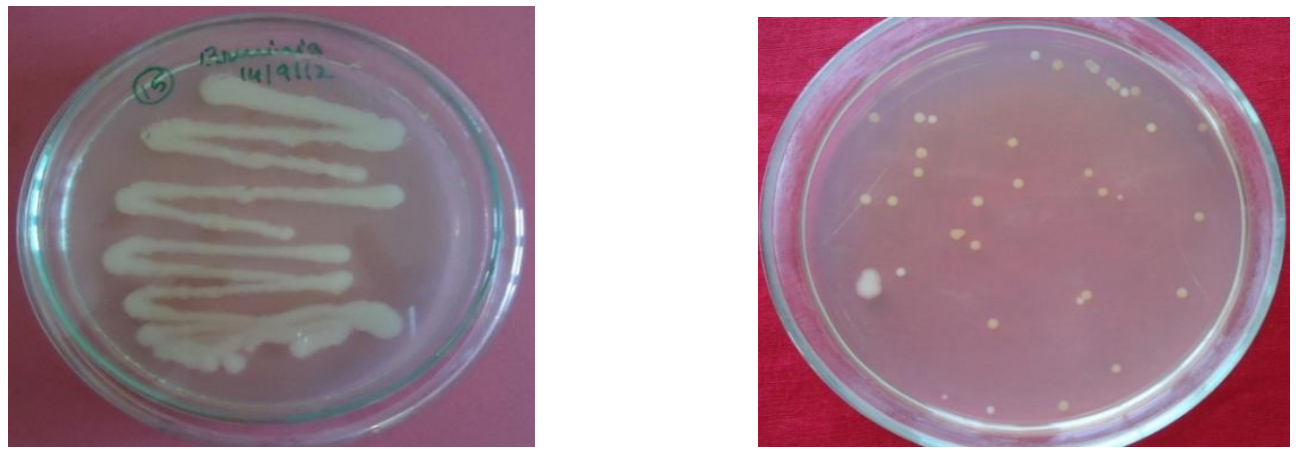

Plate.2 Pathogenicity test
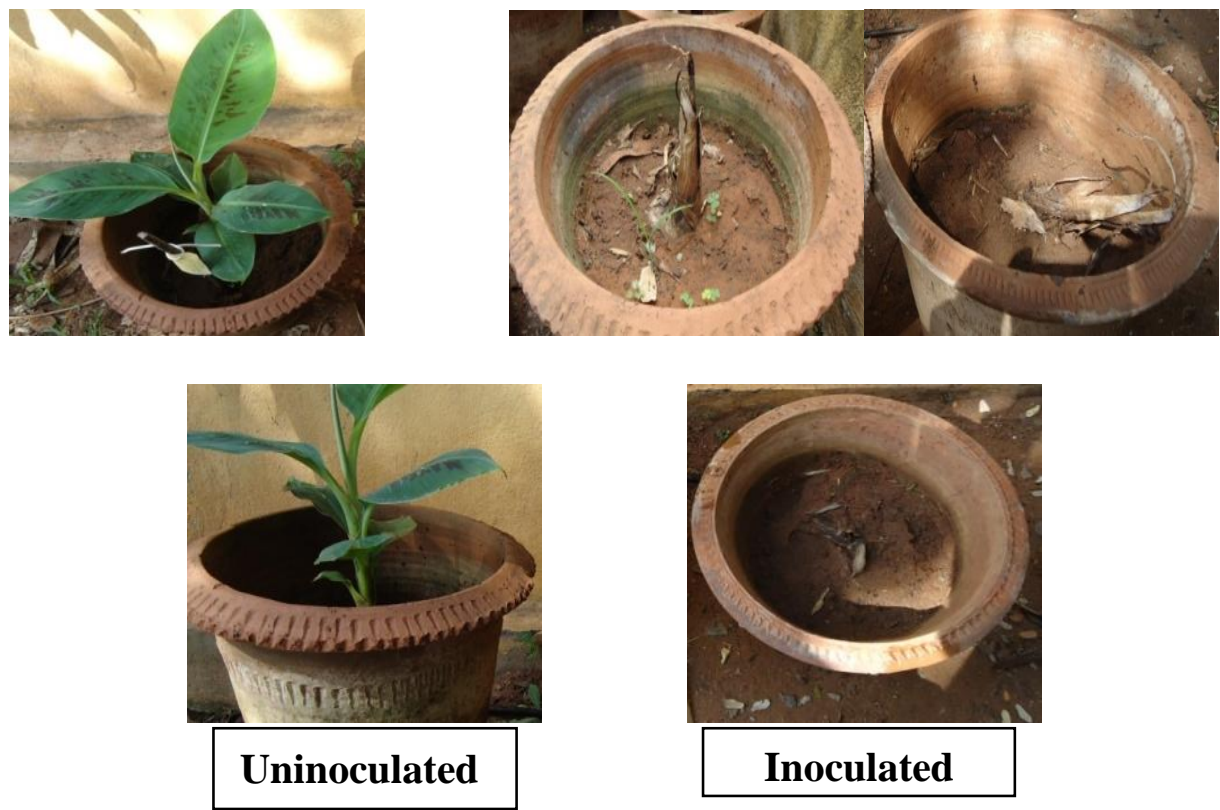
Plate.3 Hypersensitive reaction on Tobacco

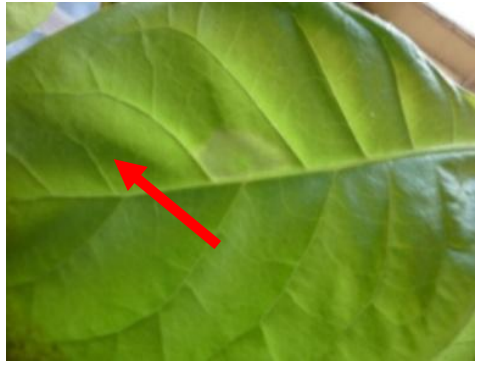

Water soaked lesion

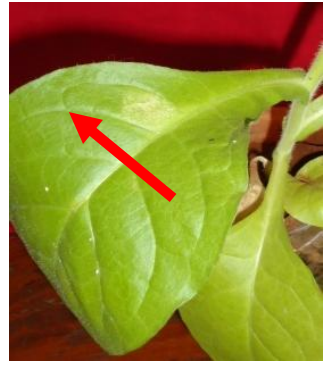

Yellowing

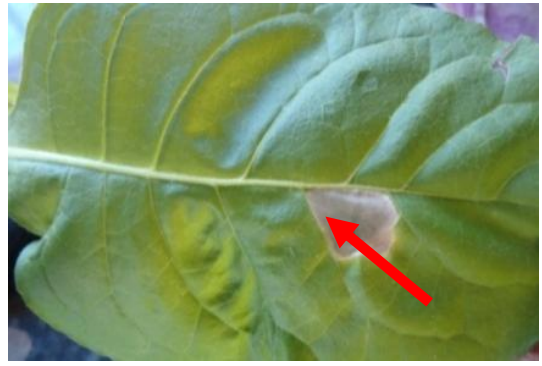

Necrosis

Plate.4 Biochemical characteristics of Erwinia chrysanthemi

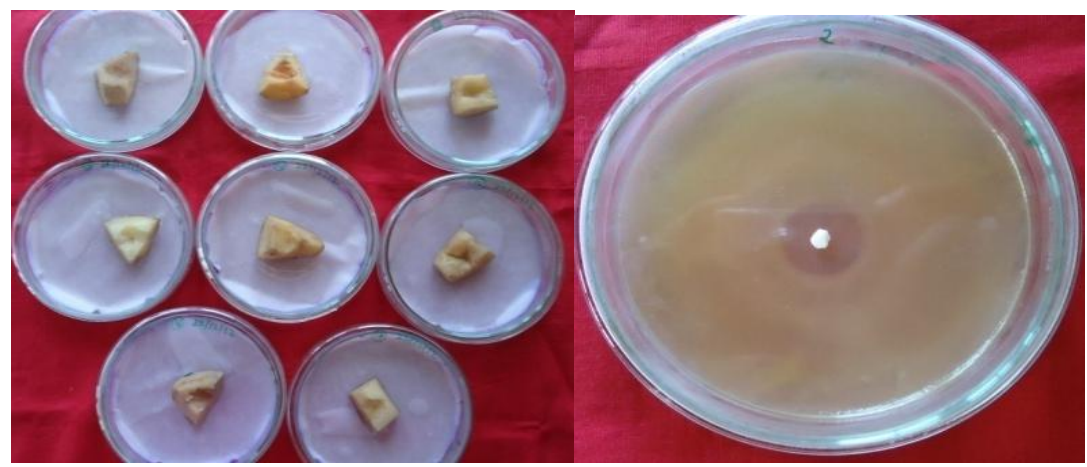

Potato soft rot

Sensitivity to erythromycin

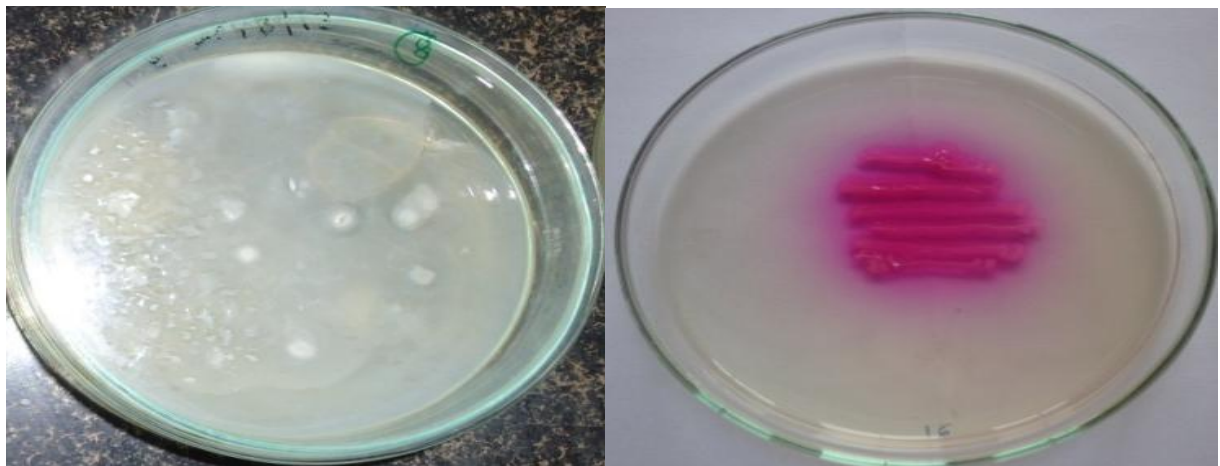

Gelatine liquifaction test

Phosphatase test

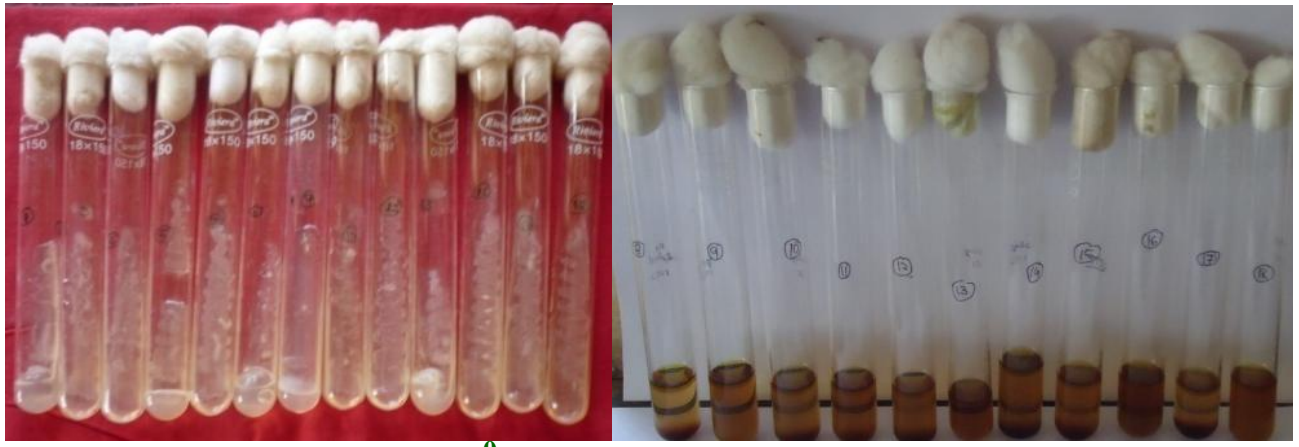

Growth at $36-37{ }^{0} \mathrm{C}$ Indole test 
Table.1 Biochemical properties useful for identification of Erwinia chrysanthemi

\begin{tabular}{|l|c|c|c|c|c|c|c|c|c|c|c|c|c|c|c|c|c|c|}
\hline \multicolumn{1}{|c|}{ Test } & $\mathbf{I}_{\mathbf{1}}$ & $\mathbf{I}_{\mathbf{2}}$ & $\mathbf{I}_{\mathbf{3}}$ & $\mathbf{I}_{\mathbf{4}}$ & $\mathbf{I}_{\mathbf{5}}$ & $\mathbf{I}_{\mathbf{6}}$ & $\mathbf{I}_{\mathbf{7}}$ & $\mathbf{I}_{\mathbf{8}}$ & $\mathbf{I}_{\mathbf{9}}$ & $\mathbf{I}_{\mathbf{1 0}}$ & $\mathbf{I}_{\mathbf{1 1}}$ & $\mathbf{I}_{\mathbf{1 2}}$ & $\mathbf{I}_{\mathbf{1 3}}$ & $\mathbf{I}_{\mathbf{1 4}}$ & $\mathbf{I}_{\mathbf{1 5}}$ & $\mathbf{I}_{\mathbf{1 6}}$ & $\mathbf{I}_{\mathbf{1 7}}$ & $\mathbf{I}_{\mathbf{1 8}}$ \\
\hline Potato soft rot & + & + & + & + & + & + & + & + & + & + & + & + & + & + & + & + & + & + \\
\hline $\begin{array}{l}\text { Sensitivity to } \\
\text { erythromycin }\end{array}$ & + & + & + & + & + & + & + & + & + & + & + & + & + & + & + & + & + & + \\
\hline $\begin{array}{l}\text { Growth at 36- } \\
37^{0} \mathrm{C}\end{array}$ & + & + & + & + & + & + & + & + & + & + & + & + & + & + & + & + & + & + \\
\hline $\begin{array}{l}\text { Gelatine } \\
\text { liquefaction }\end{array}$ & - & - & - & - & - & - & - & - & - & - & $\mathrm{V}$ & - & - & - & - & - & - & - \\
\hline Phosphatase & + & + & + & + & + & + & + & + & + & + & + & + & + & + & + & + & + & + \\
\hline Indole test & + & + & + & + & + & + & + & + & + & + & + & + & + & + & + & + & + & + \\
\hline
\end{tabular}

I: Isolate V: Variable

$I_{1}$ - Dastikoppa

$\mathrm{I}_{2}$ - Yamakanamaradi

$\mathrm{I}_{3}$ - Hattaragi

$\mathrm{I}_{4}$ - Shivapur

$I_{5}$ - Hidakal

$\mathrm{I}_{6}$ - Munavalli

\section{Hypersensitive reaction on tobacco (hr)}

The results of the studies conducted on the hypersensitive reaction are presented in the (plate 3). The bacteria injected in the intercellular spaces of tobacco leaves. The injected leaves produced characteristic water soaked lesion within few seconds, yellowing at 48 hours and necrosis during the next 96 hours. The result was in confirmation with the studies of Ouf et al., (1991) who reported four tested isolates of E. carotovora subsp. carotovora induced hypersensitive reaction in cactus (Aloe sp.) and Nicotiana glutinosa plants.

\section{Biochemical characteristics}

The results of various biochemical tests are given in Table 1 and Plate 4. All the eighteen isolates caused characteristic rotting of the potato slices. All the isolates showed sensitive to erythromycin, positive reaction for growth at $36-37{ }^{\circ} \mathrm{C}$, phosphatase test, indole test. All the isolates of the bacterium were negative to gelatine liquefaction but $I_{11}$ variable with gelatine test. On comparing the various
$\mathrm{I}_{13^{-}}$Yalahatti
$\mathrm{I}_{14}$ - Jamakhandi
$\mathrm{I}_{15}$ - Lokapur
$\mathrm{I}_{16^{-}}$Salahalli
$\mathrm{I}_{17^{-}}$Rabakavi
$\mathrm{I}_{18}$ - Rajapur

physiological and biochemical characters of the isolates with those type of typical Erwinia test mentioned by Snehalatharani and Khan (2010) who reported that reported the bacterium showing positive for pectate degradation on CVP medium, growth at $36^{\circ} \mathrm{C}$ and $39^{\circ} \mathrm{C}$, catalose production and negative for indole production. Dickey and Victoria (1980) reported that Erwinia sp. isolated from Musa paradisiaca was sensitive to erythromycin. The result of the findings confirmed the fact that all the isolates were sensitive to erythromycin.

\section{References}

Anonymous, 1957, Manual of microbial methods: Ed. Society of American Bacteriologists, Mc Graw Hill, New York, p. 135.

Anonymous, 2009, Group Discussion of All India Co-ordinated Research Project and ICAR Ad-hoc schemes on Tropical Fruits, Kerala Agri. Univ., Thrissur, and pp. 324.

Bradbury, J. F., 1970, Isolation and preliminary study of bacteria from 
plants. Rev. Pl. Pathol, 49: 213-218.

Chattopadhyay, P. K., and Mukherjee, N., 1986, A pseudostem rot of banana due to Erwinia chrysanthemi pv. paradisiaca. Curr. Sci., 55: 789-790.

Dickey, R. S., 1981, Erwinia chrysanthemi: reaction of eight plant species to strains from several hosts and to strains of other Erwinia sp. Phytopathol, 71: 2329.

Dickey, R. S., and Victoria, J. I., 1980, Taxonomy and embedded description of strains of Erwinia isolated from Musa paradisiaca Linnaeus. Int. J. Syst. Bacteriol., 30: 129-134.

Edward, J. C., Tripathi, S. C. and Singh, K. P., 1973, Observations on a tip-over disease of banana Allahabad. Curr. Sci., 42: 696-697.

Lakshmanan, P., and Mohan, S., 1986, Control of "tip-over" disease of Cavendish banana. South Indian Hort., 34: 336-337.

Lakshmanan, P., and Mohan, S., 1992, Studies on rhizome rot and "tip over" disease of banana. Madras Agric. J., 79: 56-57.

Nagaraj, M. S., Umashankar, N., Palanna, K. B. and Khan, A. N. A., 2012, Etiology and management of tip-over disease of banana by using biological agents. Int. J. Adv. Bio. Res., 2 (3): 483-486.

Ouf, M. F., Guzar, A. A., El-Sadek, S. A. M. and Galal, A. A., 1991, Response of cactus and Nicotiana glutinosa leaves to infection by soft rot bacteria. Egyptian J. Microbiol., 26: 49-58.

Schaad, N. W., Brenner, D., 1977, A bacterial wilt and root rot of sweet potato caused by Erwinia chrysanthemi. Phytopathol, 67: 302-308.

Snehalatharani, A., and Khan, A. N. A., 2010, Biochemical and physiological characterisation of Erwinia species causing tip-over disease of banana. Arch. Phytopathol and Pl. Prot., 43 (11): 1072-1080.

Stover, R. H., 1959, Bacterial rhizome rot of bananas. Phytopathol, 49: 290-292.

\section{How to cite this article:}

Vasundhara, B.A. and Thammaiah, N. 2017. Morphological and Biochemical Properties Useful for Identification of Erwinia chrysanthemi. Int.J.Curr.Microbiol.App.Sci. 6(10): 343-348. doi: https://doi.org/10.20546/ijcmas.2017.610.042 